\title{
Activation of the $\mathrm{GABA}_{\mathrm{B}}$ receptor prevents nicotine-induced locomotor stimulation in mice
}

\section{Carla Lobina ${ }^{1}$, Mauro A. M. Carai ${ }^{1}$, Wolfgang Froest ${ }^{2}$, Claudia Mugnaini ${ }^{3}$, Serena Pasquini ${ }^{3}$, Federico Corelli ${ }^{3}$, Gian Luigi Gessa ${ }^{1}$ and Giancarlo Colombo ${ }^{1}{ }^{*}$}

${ }^{1}$ Neuroscience Institute, National Research Council of Italy, Section of Cagliari, Monserrato, Italy

${ }^{2}$ AC Immune SA, Lausanne, Switzerland

${ }^{3}$ Department of Pharmaceutical and Applied Chemistry, University of Siena, Siena, Italy

\section{Edited by:}

Marco Diana, University of Sassari, Italy

\section{Reviewed by:}

Fabio Caputo, Hospital of Ferrara, Italy Michela (Micky) Marinelli, Rosalind Franklin University of Medicine and Science, USA

Carla Cannizzaro, University of

Palermo, Italy

\section{*Correspondence:}

Giancarlo Colombo, Neuroscience Institute, National Research Council of Italy, Section of Cagliari, S.S. 554, Km. 4,500, 1-09042 Monserrato,

Cagliari, Italy.

e-mail:colomb@unica.it
Recent studies demonstrated that activation of the $\mathrm{GABA}_{\mathrm{B}}$ receptor, either by means of orthosteric agonists or positive allosteric modulators (PAMs), inhibited different nicotinerelated behaviors, including intravenous self-administration and conditioned place preference, in rodents. The present study investigated whether the anti-nicotine effects of the $\mathrm{GABA}_{B}$ receptor agonist, baclofen, and GABA PAMs, CGP7930, and GS39783, extend to nicotine stimulant effects. To this end, CD1 mice were initially treated with baclofen $(0,1.25$, and $2.5 \mathrm{mg} / \mathrm{kg}$, i.p.), CGP7930 (0, 25, and $50 \mathrm{mg} / \mathrm{kg}$, i.g.), or GS39783 (0, 25, and $50 \mathrm{mg} / \mathrm{kg}$, i.g.), then treated with nicotine $(0$ and $0.05 \mathrm{mg} / \mathrm{kg}$, s.c.), and finally exposed to an automated apparatus for recording of locomotor activity. Pretreatment with doses of baclofen, CGP7930, or GS39783 that did not alter locomotor activity when given with nicotine vehicle fully prevented hyperlocomotion induced by $0.05 \mathrm{mg} / \mathrm{kg}$ nicotine. These data extend to nicotine stimulant effects the capacity of baclofen and GABA $B$ PAMs to block the reinforcing, motivational, and rewarding properties of nicotine. These data strengthen the hypothesis that activation of the $\mathrm{GABA}_{B}$ receptor may represent a potentially useful, anti-smoking therapeutic strategy.

Keywords: $\mathrm{GABA}_{B}$ receptor, baclofen, positive allosteric modulation of the $\mathrm{GABA}_{B}$ receptor, CGP7930, GS39783, nicotine-induced hyperlocomotion, mouse

\section{INTRODUCTION}

Multiple experimental and clinical data suggest that drugs activating the $\mathrm{GABA}_{\mathrm{B}}$ receptor constitute a new class of pharmacological agents with potential anti-addictive properties: treatment with both orthosteric $\mathrm{GABA}_{\mathrm{B}}$ receptor agonists and positive allosteric modulators (PAMs) of the $\mathrm{GABA}_{\mathrm{B}}$ receptor has indeed been reported to suppress several behaviors related to alcohol, cocaine, $d$-amphetamine, heroin, $\gamma$-hydroxybutyric acid, and nicotine in rodents as well as alcohol, cocaine, and nicotine taking in humans (see Addolorato and Leggio, 2010; Tyacke et al., 2010; Vlachou and Markou, 2010). Focusing on nicotine, the $\mathrm{GABA}_{\mathrm{B}}$ receptor agonists, baclofen and CGP44532, have repeatedly been reported to block (a) intravenous self-administration of nicotine (Corrigall et al., 2000, 2001; Fattore et al., 2002; Paterson et al., 2004, 2005b), (b) cue-induced reinstatement of nicotine-seeking behavior (Paterson et al., 2005b; Fattore et al., 2009), (c) conditioned place preference to nicotine (Le Foll et al., 2008), and (d) nicotineinduced lowering of threshold for intracranial self-stimulation (Paterson et al., 2005a) in rats and mice. At clinical level, treatment with baclofen reduced (a) the number of cigarets smoked per day in a double-blind placebo-controlled study (Franklin et al., 2009) and (b) cigaret enjoyment and palatability in a human laboratory study (Cousins et al., 2001).

More recently, similar data have been collected with $\mathrm{GABA}_{\mathrm{B}}$ PAMs: administration of CGP7930, GS39783, and BHF177 three of the few, presently available, in vivo effective $G_{A B A}$
PAMs - suppressed indeed (a) intravenous self-administration of nicotine (Paterson et al., 2008; Vlachou et al., 2011), (b) cueinduced reinstatement of nicotine-seeking behavior (Vlachou et al., 2011), (c) development of conditioned place preference to nicotine (Mombereau et al., 2007), and (d) nicotine-induced lowering of threshold for intracranial self-stimulation (Paterson et al., 2008), in rats. These data, suggesting that the anti-nicotine properties of baclofen extend to $\mathrm{GABA}_{B}$ PAMs, are theoretically of therapeutic interest as $G_{A B A}$ PAMs are expected to display fewer undesirable side-effects compared to $\mathrm{GABA}_{\mathrm{B}}$ receptor agonists (see Vlachou and Markou, 2010).

Low-to-moderate doses of nicotine have been repeatedly reported to stimulate locomotor activity in rats and mice (e.g., Jerlhag and Engel, 2011; for review, see Hendry and Rosecrans, 1982). Locomotor hyperactivity has been proposed to represent an index of the stimulatory and euphorigenic-like effects of drugs of abuse (see Wise and Bozarth, 1987; Phillips and Shen, 1996) and constitutes - together with self-administration, induction of conditioned place preference, facilitation of intracranial self-stimulation, and elicitation of discriminative stimulus effects similar to those of other addictive drugs - the behavioral criteria defining the addiction potential of a psychoactive drug. The present study was designed to extend to nicotine-stimulated locomotor activity the suppressing effects of baclofen and $G_{A B A}$ PAMs on several nicotine-related behaviors and address the question as to whether drugs activating the $\mathrm{GABA}_{\mathrm{B}}$ receptor may 
suppress nicotine stimulant effects, beside nicotine reinforcing, motivational, and rewarding properties (see above for references). To this end, mice were acutely pretreated with per se ineffective doses of baclofen, CGP7930, or GS39783, and then acutely treated with a stimulating dose of nicotine; immediately after nicotine administration, mice were exposed to an automated apparatus for recording of locomotor activity.

\section{MATERIALS AND METHODS}

The experimental procedures employed in the present study were in accordance with the European Communities Council Directive (86/609/EEC) and the subsequent Italian Law on the Protection of animals used for experimental and other scientific reasons.

\section{ANIMALS}

A total of $n=288$ male CD1 mice (Charles River, Calco, Italy), weighing 35-40 g, were used. Mice were housed 10 per cage in standard plastic cages with wood chip bedding. The animal facility was under a 12:12-h light-dark cycle (lights on at 7:00 a.m.), at a constant temperature of $22 \pm 2^{\circ} \mathrm{C}$ and relative humidity of approximately $60 \%$. Tap water and standard rodent chow (Mucedola, Settimo Milanese, Italy) were always available in the homecage.

\section{EXPERIMENTAL PROCEDURE}

Locomotor activity was measured in Plexiglas test cages [ $480 \mathrm{~h} \mathrm{~mm} \times 480 \mathrm{hmm} \times 400 \mathrm{hmm}$ ] by a computer-operated, photocell-equipped apparatus (Motil, TSE, Bad Homburg, Germany). Test cages were located in a sound-proof room, adjacent to the housing room. Locomotor activity sessions were conducted during the first $6 \mathrm{~h}$ of the light phase of the light/dark cycle.

Three independent experiments were conducted, each one testing separately baclofen, CGP7930, or GS39783. In each experiment, mice were divided into six independent groups of $n=14-18$ mice each. Mice were fasted $1 \mathrm{~h}$ before administration of baclofen, CGP7930, or GS39783. Locomotor activity sessions were conducted as follows: mice were (a) treated with baclofen, CGP7930, or GS39783, (b) exposed to the motility cage for $60 \mathrm{~min}$ (this initial, adaptation phase was expected to provide relatively low baseline levels of spontaneous locomotor activity at the time of nicotine treatment, i.e., a desirable condition to amplify the stimulant effect of nicotine), (c) removed and treated with nicotine, and (d) reexposed to the motility cage for a final 20-min period. Locomotor activity counts over the period preceding nicotine administration provided baseline levels. Mice from each homecage were randomly allocated to the different experimental groups and tested simultaneously. Mice were exposed to the test cage only once. At the end of each trial, the test cage was cleaned thoroughly.

Baclofen (Novartis, Basel, Switzerland) was dissolved in saline and administered at the doses of $0,1.25$, and $2.5 \mathrm{mg} / \mathrm{kg}$. Baclofen was administered intraperitoneally as this route of administration has consistently been used in most of the studies testing its anti-nicotine effects (e.g., Paterson et al., 2004; Le Foll et al., 2008; Fattore et al., 2009). CGP7930 (synthesized by WF) was dissolved in a 4:1:15 mixture containing Cremophor EL, 1,2-propanediol, and distilled water and administered at the doses of 0,25 , and $50 \mathrm{mg} / \mathrm{kg}$. GS39783 (synthesized by CM, SP, and FC) was suspended in distilled water with a few drops of Tween 80 and administered at the doses of 0, 25, and $50 \mathrm{mg} / \mathrm{kg}$. CGP7930 and GS39783 were administered intragastrically as this route of administration has consistently been used in most of the studies testing their anti-nicotine effects (e.g., Mombereau et al., 2007; Paterson et al., 2008; Vlachou et al., 2011). Nicotine (tartrate salt; Sigma, Milan, Italy) was dissolved in saline and administered subcutaneously at the doses of 0 and $0.05 \mathrm{mg} / \mathrm{kg}$ (expressed as free base). Nicotine dose, route of administration, and time of locomotor activity recording after nicotine injection were chosen on the basis of preliminary results and literature data (e.g., Freeman et al., 1987; Kita et al., 1988; Kim and Kim, 1999) as the most appropriate to detect nicotine-induced hyperactivity in mice. Injection volume was $12.5 \mathrm{ml} / \mathrm{kg}$ for all drugs.

\section{STATISTICAL ANALYSIS}

The measured variable was the total number of counts (photocell breaks) recorded automatically by the apparatus over the 20-min session. Data from each experiment were statistically analyzed by a two-way (dose of the $\mathrm{GABA}_{\mathrm{B}}$ ligand; dose of nicotine) analysis of variance (ANOVA), followed by the Newman-Keuls test for post hoc comparisons.

\section{RESULTS}

In all three experiments (testing baclofen, CGP7930, and GS39783, respectively), baseline levels - i.e., the locomotor activity occurring during the 60-min initial period of "adaptation" to the test cage - did not differ among mouse groups (data not shown).

In the experiment testing baclofen (Figure 1), ANOVA revealed a significant effect of baclofen dose $[F(2,78)=6.21, P<0.005]$, no effect of nicotine dose $[F(1,78)=0.67, P>0.05]$, and a significant interaction $[F(2,78)=7.67, P<0.001]$. Nicotine administration

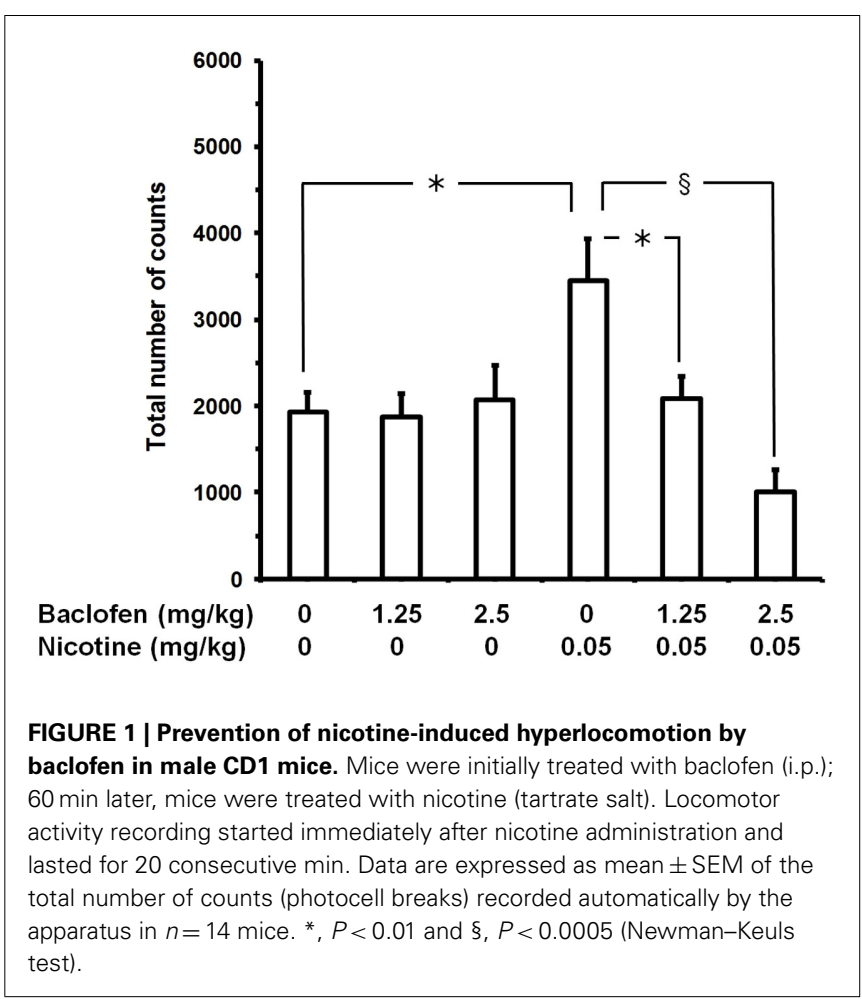


resulted in a marked stimulation of locomotor activity: at the end of the 20 -min session, the number of counts in " $0 \mathrm{mg} / \mathrm{kg}$ baclofen plus $0.05 \mathrm{mg} / \mathrm{kg}$ nicotine"-treated mice was approximately $80 \%$ higher than that recorded in control mice (" $0 \mathrm{mg} / \mathrm{kg}$ baclofen plus $0 \mathrm{mg} / \mathrm{kg}$ nicotine"). When given with nicotine vehicle, no dose of baclofen altered locomotor activity (" $1.25 \mathrm{mg} / \mathrm{kg}$ baclofen plus $0 \mathrm{mg} / \mathrm{kg}$ nicotine" and " $2.5 \mathrm{mg} / \mathrm{kg}$ baclofen plus $0 \mathrm{mg} / \mathrm{kg}$ nicotine" mouse groups). Conversely, pretreatment with both doses of baclofen resulted in complete blockade of the locomotor stimulant effect of nicotine (" $1.25 \mathrm{mg} / \mathrm{kg}$ baclofen plus $0.05 \mathrm{mg} / \mathrm{kg}$ nicotine" and " $2.5 \mathrm{mg} / \mathrm{kg}$ baclofen plus $0.05 \mathrm{mg} / \mathrm{kg}$ nicotine" mouse groups). Combination of the highest dose of baclofen and nicotine (" $2.5 \mathrm{mg} / \mathrm{kg}$ baclofen plus $0.05 \mathrm{mg} / \mathrm{kg}$ nicotine" mouse group) resulted in a tendency toward a reduction in locomotor activity compared to control mice (" $0 \mathrm{mg} / \mathrm{kg}$ baclofen plus $0 \mathrm{mg} / \mathrm{kg}$ nicotine").

In the experiment testing CGP7930 (Figure 2), ANOVA revealed a significant effect of nicotine dose $[F(1,90)=8.00$, $P<0.01]$, no effect of CGP7930 dose $[F(2,90)=2.55, P>0.05]$, and an almost significant interaction $[F(2,90)=2.95, P=0.058]$. Nicotine administration resulted in a marked stimulation of locomotor activity: at the end of the 20-min session, the number of counts in " $0 \mathrm{mg} / \mathrm{kg}$ CGP7930 plus $0.05 \mathrm{mg} / \mathrm{kg}$ nicotine"-treated mice was approximately $100 \%$ higher than that recorded in control mice (" $0 \mathrm{mg} / \mathrm{kg}$ CGP7930 plus $0 \mathrm{mg} / \mathrm{kg}$ nicotine"). When given with nicotine vehicle, no dose of CGP7930 altered locomotor activity (" $25 \mathrm{mg} / \mathrm{kg}$ CGP7930 plus $0 \mathrm{mg} / \mathrm{kg}$ nicotine" and " $50 \mathrm{mg} / \mathrm{kg}$ CGP7930 plus $0 \mathrm{mg} / \mathrm{kg}$ nicotine” mouse groups). Conversely, pretreatment with both doses of CGP7930 resulted in complete blockade of the locomotor stimulant effect of nicotine (" $25 \mathrm{mg} / \mathrm{kg}$ CGP7930 plus $0.05 \mathrm{mg} / \mathrm{kg}$ nicotine" and "50 mg/kg CGP7930 plus $0.05 \mathrm{mg} / \mathrm{kg}$ nicotine" mouse groups).

In the experiment testing GS39783 (Figure 3), ANOVA revealed a significant effect of nicotine dose $[F(1,102)=8.93, P<0.005]$, no effect of GS39783 dose $[F(2,102)=1.09, P>0.05]$, and a significant interaction $[F(2,102)=3.38, P<0.05]$. Nicotine administration resulted in a marked stimulation of locomotor activity: at the end of the 20-min session, the number of counts in “0 mg/kg GS39783 plus $0.05 \mathrm{mg} / \mathrm{kg}$ nicotine"-treated mice was approximately $110 \%$ higher than that recorded in control mice (“0 mg/kg GS39783 plus $0 \mathrm{mg} / \mathrm{kg}$ nicotine"). When given with nicotine vehicle, no dose of GS39783 altered locomotor activity (" $25 \mathrm{mg} / \mathrm{kg}$ GS39783 plus $0 \mathrm{mg} / \mathrm{kg}$ nicotine" and " $50 \mathrm{mg} / \mathrm{kg}$ GS39783 plus $0 \mathrm{mg} / \mathrm{kg}$ nicotine” mouse groups). Conversely, pretreatment with $50 \mathrm{mg} / \mathrm{kg}$ GS39783 resulted in a complete blockade of the locomotor stimulant effect of nicotine (" $50 \mathrm{mg} / \mathrm{kg}$ GS39783 plus $0.05 \mathrm{mg} / \mathrm{kg}$ nicotine" mouse group); pretreatment with $25 \mathrm{mg} / \mathrm{kg} \mathrm{GS} 39783$ produced a tendency toward a reduction of the locomotor stimulant effect of nicotine (" $25 \mathrm{mg} / \mathrm{kg} \mathrm{GS39783}$ plus $0.05 \mathrm{mg} / \mathrm{kg}$ nicotine" mouse group).

\section{DISCUSSION}

The results of the present study demonstrate the capacity of the orthosteric $G_{A B A}$ receptor agonist, baclofen, and the $G_{A B A}$ PAMs, CGP7930, and GS39783, to inhibit nicotine stimulant effects. Indeed, treatment with non-sedative doses of baclofen, CGP7930, or GS39783 completely prevented nicotine-induced
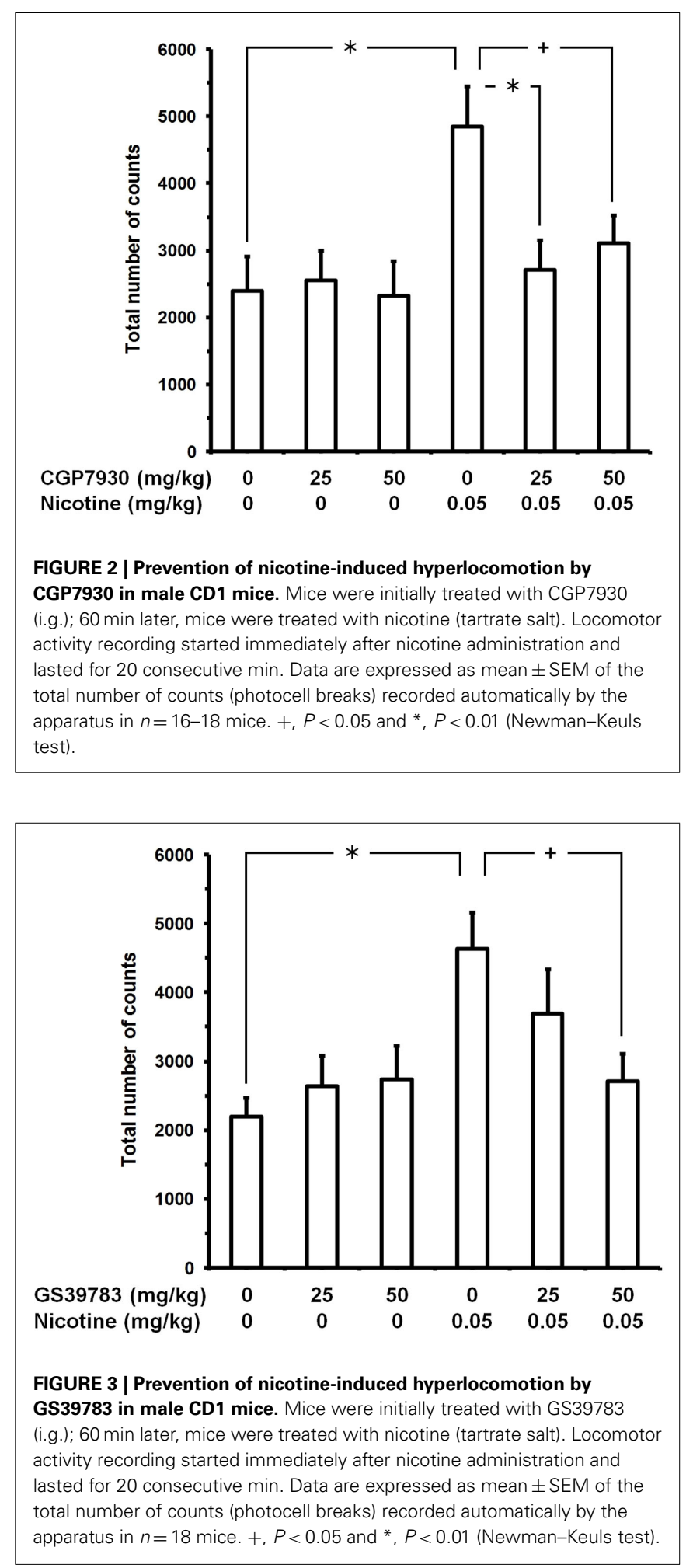

hyperlocomotion in mice. These data extend to the stimulant effects of nicotine the capacity of $\mathrm{GABA}_{\mathrm{B}}$ receptor agonists and $\mathrm{GABA}_{\mathrm{B}}$ PAMs to inhibit nicotine reinforcing, motivational, and rewarding properties in rodents. Multiple lines of experimental evidence have indeed demonstrated that treatment with the 
$\mathrm{GABA}_{\mathrm{B}}$ receptor agonists, baclofen and CGP44532, or the GABA PAMs, CGP7930, GS39783, and BHF177, suppressed (a) intravenous self-administration of nicotine, (b) cue-induced reinstatement of nicotine-seeking behavior, (c) conditioned place preference to nicotine, and (d) nicotine-induced lowering of threshold for intracranial self-stimulation in rats and mice (see the Introduction for references). Notably, data on baclofen has been extended to humans: treatment with baclofen reduced the daily number of smoked cigarets (Franklin et al., 2009) as well as cigaret enjoyment and palatability (Cousins et al., 2001).

Together, the results of the present study suggest that activation of the $\mathrm{GABA}_{\mathrm{B}}$ receptor - either by means of an orthosteric agonist or PAMs - blocks several psychopharmacological effects of nicotine; these multiple lines of experimental evidence also suggest that the $\mathrm{GABA}_{\mathrm{B}}$ receptor can be considered a promising target for development of potentially useful anti-smoking medications. $\mathrm{GABA}_{\mathrm{B}}$ PAMs are devoid of substantial intrinsic agonistic activity at the $\mathrm{GABA}_{\mathrm{B}}$ receptor: they do not perturb receptor signaling on their own, but potentiate the effect of GABA only where and when it is endogenously released (see Froestl, 2010; Urwyler, 2011). By targeting only endogenously activated receptors, rather than their whole population, PAMs are expected to produce fewer side-effects and lower tolerance. Accordingly, their anti-addictive and anxiolytic effects occur at doses considerably lower than those required to produce hypolocomotion and sedation (e.g., Cryan et al., 2004; Maccioni et al., 2008; see Vlachou and Markou, 2010). The high therapeutic index of $\mathrm{GABA}_{\mathrm{B}}$ PAMs theoretically makes these drugs clearly preferable over baclofen and other $\mathrm{GABA}_{\mathrm{B}}$ receptor agonists, the non-selective suppressant effects of which occur at doses relatively close to those producing the desirable pharmacological effects. Studies are now needed to assess whether the favorable "safety" profile of GABA ${ }_{B}$ PAMs observed in rodents may be transposed to humans; should this be the case, GABA $B$ PAMs would represent a class of improved therapeutic compounds for pharmacological intervention on GABA neurotransmission (including, to stay focused on the issue of the present study, nicotine addiction).

The data collected in the present study are also consonant with several findings indicating that pretreatment with baclofen or GS39783 suppressed hyperlocomotion induced in rats and mice by acute injection of other drugs of abuse, including alcohol (Quintanilla et al., 2008; Holstein et al., 2009), cocaine (Kalivas et al., 1990; Lhuillier et al., 2007), morphine (Woo et al., 2001; LeiteMorris et al., 2002), and $d$-amphetamine (Kalivas et al., 1990;

\section{REFERENCES}

Addolorato, G., and Leggio, L. (2010). Safety and efficacy of baclofen in the treatment of alcohol-dependent patients. Curr. Pharm. Des. 16, 2113-2117.

Bowery, N. G., Hudson, A. L., and Price, G. W. (1987). GABAA and GABAB receptor site distribution in the rat central nervous system. Neuroscience 20, 365-383.

Corrigall, W. A., Coen, K. M., Adamson, K. L., Chow, B. L., and Zhang, J. (2000). Responseof nicotine self-administration in the rat to manipulations of mu-opioid and $\gamma$-aminobutyric acid receptors in the ventral tegmental area. Psychopharmacology (Berl.) 149, 107-114.

Corrigall, W. A., Coen, K. M., Zhang, J., and Adamson, K. L. (2001). GABA mechanisms in the pedunculopontine tegmental nucleus influence particular aspects of nicotine self-administration selectively in the rat. Psychopharmacology (Berl.) 158, 190-197.

Phillis et al., 2001). Together, these data suggest that activation of the $\mathrm{GABA}_{\mathrm{B}}$ receptor may suppress the stimulant, euphorigeniclike properties of different drugs of abuse, underlining - once more - the therapeutic, anti-addictive potential of baclofen and $\mathrm{GABA}_{\mathrm{B}}$ PAMs.

It is widely thought that the addictive properties of nicotine are based on its capacity to alter the activity of the mesolimbic dopamine (DA) neurons and to enhance DA release in terminal areas (e.g., Jerlhag and Engel, 2011; for review, see Di Chiara, 2000; Mansvelder and McGehee, 2002; Laviolette and van der Kooy, 2004). These neurons originate in the ventral tegmental area (VTA) and project their axons to forebrain regions, including the nucleus accumbens $(\mathrm{NAc}) . \mathrm{GABA}_{\mathrm{B}}$ receptors are abundant in the VTA, where they are located both on cellular bodies of DA neurons and presynaptic terminals of glutamate neurons (Bowery et al., 1987); their activation inhibits the activity of mesolimbic DA neurons and DA release in the NAc (e.g., Yoshida et al., 1994; Westerink et al., 1996; Xi and Stein, 1998). These GABA $_{B}$ receptors located in the VTA are the likely site of action of the inhibitory effects of $\mathrm{GABA}_{\mathrm{B}}$ receptor ligands on nicotine reinforcing, motivational, rewarding, and stimulant properties: baclofen and $\mathrm{GABA}_{\mathrm{B}}$ PAMs would potentiate the GABAergic inhibitory tone in the VTA, suppressing nicotine-induced stimulation of mesolimbic DA neurons, DA release in the NAc, and - in turn - DA-mediated effects of nicotine. Accordingly, baclofen microinfusion into the VTA suppressed nicotine self-administration in rats (Corrigall et al., 2000).

In summary, the results of the present study demonstrate that pretreatment with the orthosteric $\mathrm{GABA}_{\mathrm{B}}$ receptor agonist, baclofen, or the GABA $\mathrm{B}$ PAMs, CGP7930, and GS39783, suppressed nicotine-induced hyperlocomotion in mice. These data generalize to nicotine stimulant effects the capacity of baclofen and $G_{A B A}$ PAMs to suppress several other properties of nicotine linked to its addictive potential. These data also strengthen the hypothesis that baclofen and $\mathrm{GABA}_{\mathrm{B}}$ PAMs may represent potentially useful medications for smoking cessation (see Tyacke et al., 2010; Vlachou and Markou, 2010).

\section{ACKNOWLEDGMENTS}

The authors are grateful to Mrs. Carla Acciaro for animal care, and Ms. Anne Farmer for language editing of the manuscript. This work has been supported by (a) Compagnia di San PaoloProgramma Neuroscienze 2008/09, Turin, Italy, and (b) European Research Advisory Board (ERAB), Lasne, Belgium.

Cousins, M. S., Stamat, H. M., and de Wit, H. (2001). Effects of a single dose of baclofen on self-reported subjective effects and tobacco smoking. Nicotine Tob. Res. 3, 123-129.

Cryan, J. F., Kelly, P. H., Chaperon, F., Gentsch, C., Mombereau, C., Lingenhoehl, K., Froestl, W., Bettler, B., Kaupmann, K., and Spooren, W. P. (2004). Behavioral characterization of the novel GABAB receptorpositive modulator GS39783 (N,N'dicyclopentyl-2-methylsulfanyl5-nitro-pyrimidine-4,6-diamine): anxiolytic-like activity without side effects associated with baclofen or benzodiazepines. J. Pharmacol. Exp. Ther. 310, 952-963.

Di Chiara, G. (2000). Role of dopamine in the behavioural actions of nicotine related to addiction. Eur. J. Pharmacol. 393, 295-314.

Fattore, L., Cossu, G., Martellotta, M. C., and Fratta, W. (2002). Baclofen antagonizes intravenous self-administration of nicotine in mice and rats. Alcohol Alcohol. 37, 495-498. 
Fattore, L., Spano, M. S., Cossu, G., Scherma, M., Fratta, W., and Fadda, P. (2009). Baclofen prevents druginduced reinstatement of extinguished nicotine-seeking behaviour and nicotine place preference in rodents. Eur. Neuropsychopharmacol. 19, 487-498.

Franklin, T. R., Harper, D., Kampman, K., Kildea-McCrea, S., Jens, W., Lynch, K. G., O'Brien, C. P., and Childress, A. R. (2009). The GABA B agonist baclofen reduces cigarette consumption in a preliminary double-blind placebocontrolled smoking reduction study. Drug Alcohol Depend. 103, 30-36.

Freeman, G. B., Sherman, K. A., and Gibson, G. E. (1987). Locomotor activity as a predictor of times and dosages for studies of nicotine's neurochemical actions. Pharmacol. Biochem. Behav. 26, 305-312.

Froestl, W. (2010). Chemistry and pharmacology of GABAB receptor ligands. Adv. Pharmacol. 58, 19-62.

Hendry, J. S., and Rosecrans, J. A. (1982). Effects of nicotine on conditioned and unconditioned behaviors in experimental animals. Pharmacol. Ther. 17, 431-454.

Holstein, S. E., Dobbs, L., and Phillips, T. J. (2009). Attenuation of the stimulant response to ethanol is associated with enhanced ataxia for a GABAA, but not a GABAB, receptor agonist. Alcohol. Clin. Exp. Res. 33, 108-120.

Jerlhag, E., and Engel, J. A. (2011). Ghrelin receptor antagonism attenuates nicotine-induced locomotor stimulation, accumbal dopamine release and conditioned place preference in mice. Drug Alcohol Depend. 117, 126-131.

Kalivas, P. W., Duffy, P., and Eberhardt, H. (1990). Modulation of A10 dopamine neurons by gammaaminobutyric acid agonists. J. Pharmacol. Exp. Ther. 253, 858-866.

Kim, H. S., and Kim, K. S. (1999). Inhibitory effects of ginseng total saponin on nicotine-induced hyperactivity, reverse tolerance and dopamine receptor supersensitivity. Behav. Brain Res. 103, 55-61.

Kita, T., Nakashima, T., Shirase, M., Asahina, M., and Kurogochi, Y. (1988). Effects of nicotine on ambulatory activity in mice. Jpn. J. Pharmacol. 46, 141-146.
Laviolette, S. R., and van der Kooy, D. (2004). The neurobiology of nicotine addiction: bridging the gap from molecules to behaviour. Nat. Rev Neurosci. 5, 55-65.

Le Foll, B., Wertheim, C. E., and Goldberg, S. R. (2008). Effects of baclofen on conditioned rewarding and discriminative stimulus effects of nicotine in rats. Neurosci. Lett. 443, 236-240.

Leite-Morris, K. A., Fukudome, E. Y., and Kaplan, G. B. (2002). Opiateinduced motor stimulation is regulated by $\gamma$-aminobutyric acid type $B$ receptors found in the ventral tegmental area in mice. Neurosci. Lett. 317, 119-122.

Lhuillier, L., Mombereau, C., Cryan, J. F., and Kaupmann, K. (2007). GABAB receptor-positive modulation decreases selective molecular and behavioral effects of cocaine. Neuropsychopharmacology 32, 388-398.

Maccioni, P., Fantini, N., Froestl, W., Carai, M. A. M., Gessa, G. L., and Colombo, G. (2008). Specific reduction of alcohol's motivational properties by the positive allosteric modulator of the GABAB receptor, GS39783 - comparison with the effect of the GABAB receptor direct agonist, baclofen. Alcohol. Clin. Exp. Res. 32, 1558-1564.

Mansvelder, H. D., and McGehee, D. S. (2002). Cellular and synaptic mechanisms of nicotine addiction. J. Neurobiol. 53, 606-617.

Mombereau, C., Lhuillier, L., Kaupmann, K., and Cryan, J. F. (2007). GABAB receptor-positive modulation-induced blockade of the rewarding properties of nicotine is associated with a reducti on in nucleus accumbens $\triangle$ FosB accumulation. J. Pharmacol. Exp. Ther. 321, 172-177.

Paterson, N. E., Bruijnzeel, A. W., Kenny, P. J., Wright, C. D., Froestl, W., and Markou, A. (2005a). Prolonged nicotine exposure does not alter GABAB receptor-mediated regulation of brain reward function. $\mathrm{Neu}$ ropharmacology 49, 953-962.

Paterson, N. E., Froestl, W., and Markou, A. (2005b). Repeated administration of the GABAB receptor agonist CGP44532 decreased nicotine self-administration, and acute administration decreased cueinduced reinstatement of nicotineseeking in rats. Neuropsychopharmacology 30, 119-128.

Paterson, N. E., Froestl, W., and Markou, A. (2004). The GABAB receptor agonists baclofen and CGP44532 decreased nicotine self-administration in the rat. Psychopharmacology (Berl.) 172, 179-186.

Paterson, N. E., Vlachou, S., Guery, S., Kaupmann, K., Froestl, W., and Markou, A. (2008). Positive modulation of GABAB receptors decreased nicotine self-administration and counteracted nicotine-induced enhancement of brain reward function in rats. J. Pharmacol. Exp. Ther. 326, 306-314.

Phillips, T. J., and Shen, E. H. (1996) Neurochemical bases of locomotion and ethanol stimulant effects. Int Rev. Neurobiol. 39, 243-282.

Phillis, B. D., Ong, J., White, J. M., and Bonnielle, C. (2001). Modification of d-amphetamineinduced responses by baclofen in rats. Psychopharmacology (Berl.) 153, 277-284.

Quintanilla, M. E., Perez, E., and Tampier, L. (2008). Baclofen reduces ethanol intake in high-alcoholdrinking University of Chile bibulous rats. Addict. Biol. 13, 326-336.

Tyacke, R. J., Lingford-Hughes, A., Reed, L. J., and Nutt, D. J. (2010). GABAB receptors in addiction and its treatment. Adv. Pharmacol. 58, 373-396.

Urwyler, S. (2011). Allosteric modulation of family C G-protein-coupled receptors: from molecular insights to therapeutic perspectives. Pharmacol. Rev. 63, 59-126.

Vlachou, S., Guery, S., Froestl, W., Banerjee, D., Benedict, J., Finn, M. G., and Markou, A. (2011). Repeated administration of the GABAB receptor positive modulator BHF177 decreased nicotine self-administration, and acute administration decreased cueinduced reinstatement of nicotine seeking in rats. Psychopharmacology (Berl.) 215, 117-128.

Vlachou, S., and Markou, A. (2010). GABAB receptors in reward processes. Adv. Pharmacol. 58, 315-371.
Westerink, B. H., Kwint, H. F., and deVries, J. B. (1996). The pharmacology of mesolimbic dopamine neurons: a dual-probe microdialysis study in the ventral tegmental area and nucleus accumbens of the rat brain. J. Neurosci. 16, 2605-2611.

Wise, R. A., and Bozarth, M. A. (1987). A psychomotor stimulant theory of addiction. Psychol. Rev. 94, 469-492.

Woo, S. H., Kim, H. S., Yun, J. S., Lee, M. K., Oh, K. W., Seong, Y. H., Oh, S. K., and Jang, C. G. (2001) Inhibition of baclofen on morphineinduced hyperactivity, reverse tolerance and postsynaptic dopamine receptor supersensitivity. Pharmacol. Res. 43, 335-340.

Xi, Z. X., and Stein, E. A. (1998). Nucleus accumbens dopamine release modulation by mesolimbic GABAA receptors - an in vivo electrochemical study. Brain Res. 798, 156-165.

Yoshida, M., Yokoo, H., Tanaka, T., Emoto, H., and Tanaka, M. (1994). Opposite changes in the mesolimbic metabolism in the nerve terminal and cell body sites induced by locally infused in the rat. Brain Res. 636, 111-114.

Conflict of Interest Statement: The authors declare that the research was conducted in the absence of any commercial or financial relationships that could be construed as a potential conflict of interest.

Received: 12 September 2011; accepted: 13 December 2011; published online: 30 December 2011.

Citation: Lobina C, Carai MAM, Froestl W, Mugnaini C, Pasquini S, Corelli F, Gessa GL and Colombo G (2011) Activation of the $G A B A_{B}$ receptor prevents nicotine-induced locomotor stimulation in mice. Front. Psychiatry 2:76. doi: 10.3389/fpsyt.2011.00076

This article was submitted to Frontiers in Addictive Disorders, a specialty of Frontiers in Psychiatry.

Copyright () 2011 Lobina, Carai, Froestl, Mugnaini, Pasquini, Corelli, Gessa and Colombo. This is an open-access article distributed under the terms of the Creative Commons Attribution Non Commercial License, which permits noncommercial use, distribution, and reproduction in other forums, provided the original authors and source are credited. 